\title{
Agoraphobia and Music Education: Fear of the Closed, Fear of the Open
}

\author{
Deborah Bradley
}

This review of Randall Everett Allsup's book, Remixing the Classroom: Toward an Open Philosophy of Music Education (Allsup 2016) deconstructs some of the characteristics of postmodernism found within the text, critiquing Allsup's use of anecdotes to set up the argument for an open philosophy of music education as an approach that relies upon the "literary tricks and strategic exclusions" (Knights 1997) common to many postmodern arguments. These strategies lead to a totalizing narrative based upon a binary construction of open/closed philosophy, combined with the strategic exclusion of substantive discussion related to issues of social justice; in Allsup's text, social justice becomes subsumed under calls for human relationships and human flourishing. The review concludes with a call to use texts such as Allsup's as an opportunity to engage in ongoing critical and crucial dialogue about the many important issues with which music educators must wrestle in today's world.

Keywords: Dualism, social justice, human flourishing, praxial music education, critical pedagogy

Agoraphobia: an anxiety disorder involving intense fear of any situation where escape may be difficult, or where help may not be available. It often involves a fear of crowds, bridges, of being outside alone, or of wide, open spaces. (McIntosh 2015)

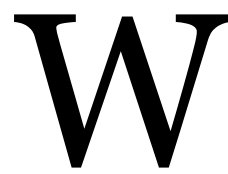

riting a book is an accomplishment to be celebrated, particularly when the book presents fresh perspectives on topics that may have stagnated over time. Such is the case with Randall Allsup's Remixing the Classroom: Toward an Open Philosophy of Music Education (Allsup 2016). Allsup provides music educators with ideas that draw from a wide range of philosophical perspectives that in combination suggest ways to bring life to

(C) Deborah Bradley 2017. The content of this article is the sole responsibility of the author. The ACT Journal and the Mayday Group are not liable for any legal actions that may arise involving the article's content, including, but not limited to, copyright infringement. 
(presumedly stagnant) music classrooms and pedagogies. Allsup employs an engaging writing style that captures readers quickly; the various anecdotes help to set up arguments that offer interesting twists for readers to ponder. As jumping off points to subsequent arguments, these anecdotes, from both inside and outside of musical discourses, move readers beyond the (again presumedly) bounded music education universe to perspectives informed from the world beyond music teaching and learning. For this reason, I recommend reading Allsup's book-for the creativity of ideas contained within its pages, and for his very engaging prose. I also recommend reading the book because of its ability to encourage readers to confront their own beliefs about music, education, and pedagogy.

Like most serious authors, Allsup presents arguments that can be interpreted from a variety of perspectives; this is in part intentional, I suspect, given the book's title, Remixing the Classroom. His bricolage of philosophical perspectives draws from diverse authors including Roland Barthes, John Dewey, and Maxine Greene. Such broadly-drawn perspectives, however, present readers with a twoedged sword: while providing the terrain upon which interesting arguments may be developed, it denies some of the important prior thinking upon which music educators have, at least in part, developed their personal teaching philosophies (and I include Allsup in this category). Such denial is common among postmodernist thinkers; indeed, postmodernist thinking may be summarized as illustrative of the following characteristics:

- Resistance towards certainty and resolution;

- Rejection of fixed notions of reality, knowledge, or method;

- Acceptance of complexity, of lack of clarity and of multiplicity;

- Acknowledgement of subjectivity, contradiction and irony;

- Irreverence for traditions of philosophy or morality;

- Deliberate intent to unsettle assumptions and presuppositions;

- Refusal to accept boundaries or hierarchies in ways of thinking; and

- Disruption of binaries that define things as either/or. (Atkinson 2010, 74)

At face value, this list of characteristics offers some allure; the appeal lies in the purported ability to liberate readers from strictly bounded systems of reason- 
ing. I can certainly relate to this sense of freedom from the "tyranny of philosophy" that postmodernism claims. I recall that as a master's student, I read Contingency, Irony, and Solidarity (Rorty 1989). After my initial struggles with the density of Rorty's writing, I began to think that the postmodern turn offered exactly the perspective that I had been seeking, particularly with respect to issues of multicultural education. Over time, however, as I read more broadly and encountered other perspectives and philosophies, I began to realize that the liberation I once thought I had found in postmodernism represented an unfulfillable promise dependent upon "a series of strategic exclusions or literary tricks" that often replicated precisely what it condemned (Knights 1997, 16).

The strategic exclusions and literary tricks called into play in Remixing the Classroom provide the basis for my remaining thoughts in this review. Like other review issues in Action, Criticism, and Theory for Music Education, my goal for the following discussion is to encourage richer, more vigorous dialogue about the many important issues facing music education today to which Allsup calls attention. I believe there are many ways in which music educators may provide "open" approaches to teaching even within what Allsup terms as "closed" philosophies, and it is with respect to such issues that we need to continue to think deeply and discuss thoroughly. Such a dialogue "has an important role to play in the social and political field, along with others who play similar roles from different philosophical or theoretical perspectives" (Atkinson 2010, 80).

\section{“Literary Tricks"}

As mentioned previously, Allsup's writing style is quite engaging, and because of his fluidity with language, he is easily able to draw upon some of the "literary tricks" (Knights 1997) for which postmodernism has been criticized. Allsup draws the reader into his argument immediately with the first anecdote of the book: the description of Dapper Dan's hip-hop clothing shop in Harlem, in which he presents proprietor Daniel Day as "a bricoleur, a bandit, a master at regifting" who riffed on the rules that applied, changed the rules that did not apply, and created something "right for one place" (Allsup 2016, 5) - key points in Allsup's arguments for an "open" philosophy. The description of Dapper Dan enchants; one can easily picture the shop, the rebranded and remixed clothing styles, and the 
customers who may have frequented Dapper Dan's store. The narrative serves to foretell the direction the book's later arguments will take, particularly as Allsup asks readers what kind of education might have prepared Dapper Dan for "such an open and imaginative life" (6). The Dapper Dan story segues to discussion of a new agenda for university music schools: to seek out bricoleurs and innovators and provide an environment that encourages their flourishing.

The anecdote, however, stops short when one realizes that the property on which Dapper Dan's store existed has, like the clothing once made and sold there, been "repurposed"; the site now hosts the Harlem Children's Zone Promise Academy, a "chain school" (6) that provides identical services and standardized quality assurance in each of its locations. It seems that Dapper Dan's inventiveness and creativity could not overcome the neoliberal takeover of education that the Harlem Children's Zone Academy represents. Allsup does not address whether the statement about universal services and quality is actually possible-a concept that I believe most educators would reject-choosing instead to let the chain school description stand as an example of the negative image against which his arguments develop, thus side-stepping an opportunity to discuss neoliberalism's intrusion into education.

Allsup moves his argument forward with another anecdote-that of Jiro Ono, a Japanese master chef whose teaching method consists of long years of directed, dictatorial instruction, during which an apprentice chef has no opportunity to experiment with his or her own culinary ideas. Allsup posits that after 10 years, the apprentice likely has "lost the ability or desire to make something new" (Allsup 2016, 18). The reader easily draws the analogy to conservatory-type musical training that may be differentiated from musical education (see Bowman 2002), and from which music graduates emerge with solid knowledge about the canon and its musical conventions, but with little other knowledge. I have also written about this fixation on the canon and its detriment to music teacher education (Bradley 2006, 2007, 2008, 2011), and so I understand Allsup's concern as one that music educators must address seriously. This is not a new concern, however, and many, including Allsup (2015), have written about how teacher education has stagnated within "the Law" (Allsup 2016, 14) of rigid pedagogies, from adherence to state and national standards for teacher education,

Bradley, Deborah. 2017. Agoraphobia and music education: Fear of the closed, fear of the open. Action, Criticism, and Theory for Music Education 16 (1): 38-52. doi:10.22176/act16.1.38 
and from students' own fears of moving beyond the comfort provided by these standards, fears which teacher educators too often tolerate (Allsup 2015).

I recall my own undergraduate music teacher education, which contrasted considerably from the rigid picture Allsup paints. Acquired in a conservatorystyle School of Music located in a traditional university, the program emphasized the Western canon and coursework included the "closed pedagogical forms" of theory and ear training. Yet I also experienced many opportunities to experiment with other musical forms, traditions, and even my own interpretations of the pipe organ repertoire that dominated my applied music studies. As part of the music education degree requirements, students took at least one world music performance ensemble, and the history sequence began with a world music survey course. My music education professors encouraged me to think freely and to "think in action" (Elliott 1995, Elliott and Silverman 2014) both as a performer and as a teacher; I do not recall feeling confined by any particular set of "rules" other than important cautions about assumptions about people or groups, and gendered language.

While I agree with Allsup that things must change within music education, I'm not sure the situation is quite as bleak as the picture he paints in Remixing the Classroom. Certainly, there has been considerable change occurring in elementary music education, at least in content if not always in pedagogy. In this statement I refer to the somewhat rigid methodolatries (Regelski 2002) of Orff and Kodaly, despite their adaptation and appropriation of global musical practices which might otherwise have allowed for less rigid pedagogies. Allsup's concerns about closed musical forms and pedagogies apply in such cases; even so, not all elementary teachers teach according to methodological rigidity, as Hess (2013) described in her doctoral thesis.

In what may be another promising front, universities and academic organizations in many locations have already begun the self-interrogation that will hopefully lead to long-overdue changes to traditional university music studies. Two examples come to mind: the 2014 College Music Society's "manifesto" (Sarath et al. 2014) calling for significant revisions to traditional undergraduate music degree programs, and a recent book project highlighting where such changes have already begun to appear in university music studies (Bradley 2017, Moore 2017). Indeed, Allsup himself points to exceptions to the "rules" of pedagogical

Bradley, Deborah. 2017. Agoraphobia and music education: Fear of the closed, fear of the open. Action, Criticism, and Theory for Music Education 16 (1): 38-52. doi:10.22176/act16.1.38 
encounters, referring to an article by music educator Cathy Benedict (Allsup 2016, 115). Although in the article Benedict laments the self-imposed return to "the business of music teaching" by the student teachers she observed (Benedict 2012, 156), and Allsup uses her description to further his argument about the imposition of closed forms, the example suggests a potential crack in the armor of closed teaching approaches, the potential for openness to occur spontaneously. Creative humans find ways to be creative; while the students in Benedict's example may have returned to the business of teaching, the fact that they ventured beyond, at least temporarily, suggests that they may do so again when they are no longer under the pressure of a supervisor's observation or concerns about their student teaching semester grade.

I do not want the reader to infer from my counter arguments that no further changes are required within music education. Far from it; most of my own writing is about precisely this need for change-my point is that Allsup employed the literary trick of a totalizing discourse to mount his argument. In contrast to the postmodern aversion to binary constructions, Allsup's argument relies on a dualism of open/closed forms and philosophies (despite his own arguments against universal binaries on pages 13 and 134 of Remixing); Allsup makes his case for openness with engaging examples such as Dapper Dan, and cautionary tales such as the description of Jiro Ono, and the story of Johanna, who was told by her "committee of Masters" (Allsup 2016, 9) that she was not "good enough" to be a musician. Allsup leads the reader to his construction of an "open" classroom or philosophy with some subtlety through these anecdotes; even so, he relies upon a perhaps "less crude," but "equally determinist" approach to the open/closed dualism in which "one side of the dualism is always privileged, albeit defined in contrast to, and therefore dependent upon, the other" (Knights 1997, 12).

Allsup utilized this tactic to paint a rather dark picture of praxial music education (Elliott 1995, Elliott and Silverman 2014). Focusing on the concept of musical apprenticeship, Allsup argues that praxial musical instruction represents a closed form of music teaching, much in the way that master chef Jiro Ono constrained and thus foreclosed the efforts of the apprentice chef. In doing so, however, Allsup glosses over an important point that his own argument shares with praxial approaches to music education; music learning occurs through doing,

Bradley, Deborah. 2017. Agoraphobia and music education: Fear of the closed, fear of the open. Action, Criticism, and Theory for Music Education 16 (1): 38-52. doi:10.22176/act16.1.38 
and this involves experimentation. Although I, too, have at times been critical of praxial music education, particularly for the perhaps unintended consequence of breathing new life into large ensemble approaches to music education (Bradley 2012), there is no reason to assume that all large ensembles represent completely closed forms of musical expression or that teachers of such ensembles only adhere to rigid conductor-teacher roles that do not allow for experimentation. Allsup draws upon the Orpheus Chamber Orchestra as an example of an open ensemble, and I think here of the work of O'Toole (1994b, 1994a), who encouraged students to have a voice in their own choral instruction. I think as well of my own university undergraduate music education. I was always encouraged to give students the chance to make their own discoveries about what may "work" musically, and to draw on the students' own expertise to create unique and meaningful musical outcomes. Detailed lesson planning was discouraged as a way to free us as student teachers from imposed expectations and to allow for creative response to our students' demonstrations of musicianship. It bears mentioning here that David Elliott, of whom Allsup's text is quite critical, was one of the professors during my undergraduate music education studies who discouraged the use of detailed lesson plans as a technology that would stifle, rather than aid, my creative abilities as a teacher.

As Elliott and Silverman (2014) argue, music making involves "experiential musical thinking and knowing" (MTK) that, when put into practice, creates the sort of uncertainty, the "laboratory" style learning, for which Allsup advocates in the late pages of the book. Elliott and Silverman state:

It's not the case that for every action of listening and musicing there is a verifiable principle that always works and that can always be reduced to words. Principles of music making, like chess strategies, don't guarantee success. They are always provisional. The effectiveness, flexibility, and portability of musical understanding hinges on the felt, artistic, and creative deployment of all forms of MTK (Elliott and Silverman 2014, 221).

The above provides just one example in Allsup's text where his arguments align with, rather than refute, those of praxial music educators, particularly Elliott and Silverman. The literary trick of citing those authors as an example of a closed philosophy of music education may convince those unfamiliar with the tenets of praxial music education, but for those who understand praxialism's primary arguments, the trick seems somewhat cheap. Praxial music education is not

Bradley, Deborah. 2017. Agoraphobia and music education: Fear of the closed, fear of the open. Action, Criticism, and Theory for Music Education 16 (1): 38-52. doi:10.22176/act16.1.38 
inherently a closed form; creativity, improvisation, and musical thinking in action are important elements of that philosophy. Allsup's focus on one specific argument (master-apprentice) in Elliott's (1995) book to label praxialism as a closed system misrepresents the breadth of thinking that praxialism offers.

\section{Strategic Exclusions}

"The persuasiveness of any text depends on a series of strategic exclusions or literary tricks and often replicates precisely what it condemns" (Knights 1997, 16). I turn now to one such exclusion in Allsup's text: issues of social justice and equity in music education. These issues demand an interrogation of any and all situations that may replicate the injustices or inequities. As a reader I found it curious that Allsup devoted so little attention in his text to social justice because I have heard him speak many times on the role of music education in perpetuating inequities and the role that music education might play in making education more just for all students. Yet within Remixing the Classroom, such issues seem to lurk just under the surface of the text without actually being named, subsumed under the perhaps less threatening language of "human relationships" (Allsup 2016, 133) and "human flourishing" (139). For example, in arguing for open forms as a way to improve teacher-student relationships too often bounded by adherence to "the Law" of the Common Core Standards (in the United States), Allsup admits that breaking away from closed forms to the adoption of open forms of teaching cannot "guarantee that a break will lead to a more socially just outcome" (134), but what he means by a more socially just outcome, and for whom it may be more just, remains undefined throughout the text.

One of the critiques of postmodernism is its lack of attention to social justice. "It has been argued ... that postmodernism can have no agenda for social justice, as it refuses to commit itself to any one political standpoint or ideological position" (Atkinson 2010, 74). Allsup's omission of direct discussion around social justice is also curious if Atkinson is correct in her assertion that "postmodern thinking prevents us from taking the signifier 'justice' for granted" and "presents itself as an 'inevitable' agent for change" (75). Yet it seems to me that avoiding direct discussion about any specific issue of social justice (race, gender, ability or (dis)ability, language, religion, and so forth), or even avoidance of a general

Bradley, Deborah. 2017. Agoraphobia and music education: Fear of the closed, fear of the open. Action, Criticism, and Theory for Music Education 16 (1): 38-52. doi:10.22176/act16.1.38 
discussion of the term, renders any philosophy mute on those issues, similar to the way Mica Pollock identified the refusal to speak about issues of race in education as rendering educators "colormute" (Pollock 2004). Alluding to issues of social justice solely through a critique of power serves as both a literary trick and a strategic exclusion. Through such omission, "postmodernism does not serve the disempowered, but frequently collapses into a form of toothless liberalism and airbrushed insurgency (McLaren and Farahmandpur 2000, 26). While I won't go so far as to say that Allsup's arguments are "toothless," since they do present a provocation that is worth serious consideration, the description of "airbrushed insurgency" resonates. If readers are to assume that Allsup's concerns for human relationships and human flourishing include issues of social justice (serving as euphemisms for social justice?), then indeed the profound problems facing students who are marginalized in today's society have been airbrushed through language that fails to provoke. McLaren and Farahmandpur asked:

Is the practice of ignoring ... contradictions and inconsistencies of culture structurally advantageous to capitalist relations of exploitation? Do such contradictions left conspicuously unaddressed merely-or mainly-provide ballast to reigning hegemons... ? (McLaren and Farahmandpur 2000, 27)

Stated another way, does ignoring direct discussion of issues of social justice in education serve as yet another "graceful, liberal gesture" (Morrison 1992) to avoid what may be uncomfortable conversation? Or does the omission serve another purpose? Just as race is often the item that "falls off the table" in discussions of oppression (Dei 2000, Ladson-Billings 1996), Allsup's text causes me to wonder if the topic of social justice in general has become discursively tired, or even toxic, so that it must be subsumed under the language of human flourishing.

Perhaps avoiding the language of social justice goes deeper than literary tricks and strategic exclusions. Perhaps the problem represents the stronghold of neoliberalism on our thinking. Attempts such as Allsup's to cast off the neoliberal stronghold, against which he also argues in the final chapter, may inadvertently result in "domesticated versions of critical pedagogy" that "argue that their purpose is mainly to 'empower' students and 'transform' education (McLaren 2011, 135). Certainly, Allsup's purposes include empowerment and transformation; the work of Paulo Freire receives mention in Remixing the Classroom as

Bradley, Deborah. 2017. Agoraphobia and music education: Fear of the closed, fear of the open. Action, Criticism, and Theory for Music Education 16 (1): 38-52. doi:10.22176/act16.1.38 
one of the starting points for Allsup's arguments. McLaren continues his argument about domesticated versions of critical pedagogy as follows:

By this they mean that teaching and learning should give students a greater sense of personal voice and agency in assisting them to carve a niche for themselves within the existing social order. However, not to interrogate further such seemingly keystone terms is to lure critical educators into the very zone of neutrality against which they inveigh. (McLaren 2011, 135)

It seems to me that, while perhaps not intended, Allsup similarly lures readers into a zone of neutrality, an acceptance of his arguments as the new panacea for the problems of music education that ignores some of the most important and politically-charged issues the discipline faces. It is, of course, up to readers to discern where arguments ring true or fall short, but when language is used skillfully, as it is in Allsup's text, readers not accustomed to critical reasoning may easily accept his words as the new reality for music education.

\section{A Case of Agoraphobia?}

In the title of this article, agoraphobia serves as a metaphor for fear of closed philosophies and pedagogies, which according to Allsup's argument (and with which I agree) represent a dire situation that music educators must begin to disrupt and abandon. However, a complete definition of the term includes "fear of any situation where escape may be difficult, or where help may not be available." In this sense, the term agoraphobia serves as a double entendre, because the term may also indicate a fear of "being outside alone," or the "fear of wide, open spaces" (McIntosh 2015). I can imagine that readers, depending on their perspectives, will respond to Allsup's text based upon their own relationship to agoraphobia. Those who believe that praxial (and other) philosophies represent or reinforce closed systems of reasoning will likely respond positively, believing that moving "toward an open philosophy of music education" (Allsup 2016) provides a perspective previously missing from music education thought. Those who want highly structured guidelines upon which to develop their pedagogies (and here I think of those wedded to Orff- and Kodaly-based approaches) will likely reject his arguments outright. Educators who base their pedagogies on praxial approaches to music education may similarly find themselves pondering whether Allsup's points have validity; does praxial music education actually 
represent a closed system of reasoning, as Allsup suggests? It is to this last group-those practioners who consider themselves to "live on the virgule" between the closed/open binary, that I suspect Allsup's text may offer the most value, because it does provoke an interrogation of whatever our systems of reasoning may be and the pedagogical practices that emerge from those systems.

I will speak personally here. As I began reading Remixing the Classroom, I often found myself agreeing with Allsup on some of his critiques of praxial music education and Elliott's (1995) master-apprentice argument. But I soon began to find myself mentally arguing with the text and the way Allsup's argument seemed to leave little room for a space between open and closed. As I continued to read, my concerns for social justice, or the lack thereof in Allsup's text, began to "worry" me, and I searched more intently for places within that text that might address those concerns explicitly, but was left disappointed, finding only vague references to human relationships and human flourishing in places where strong arguments to support social justice pedagogies could just as easily have been written.

Perhaps my critique of Allsup's text actually reflects my own anxieties. I have based my remarks in this book review on two key concepts: literary tricks and strategic exclusions. Anyone who has done any sort of serious writing understands, however, that we all make choices when putting words to paper. We use whatever discursive "tricks" get us into the systems of reasoning required to make our points. We deliberately choose to talk about some issues at the exclusion of others, occasionally even when those issues float like proverbial "elephants in the room" around the words we choose. It can be frustrating for a reader when an author does not confront the elephants that may seem so obvious to that reader, just as I was frustrated by Allsup's lack of direct discussion about issues of social justice in music education.

Even so, the various tricks and exclusions employed by an author do not render a text unworthy of consideration; the fact that reading such a text causes the reader to think about what may be misstated, overstated, or missing from an argument represents an important goal of critical thinking. Critical thinking involves reasonable, reflective thinking that leads one to focus on what to believe or to do. It is not employed for the purpose of solving problems-one uses critical thinking to improve one's process of thinking. I trust that readers of Allsup's text can avoid the sort of polarization of opinion that so often leads to a failure of Action, Criticism, and Theory for Music Education 16 (1): 38-52. doi:10.22176/act16.1.38 
dialogue. "The temptation for each side to select the worst faults of its opponents for criticism is strong enough to lead the embattled sides away from any serious sort of engagement at all, or simply to dismiss each other as not worth talking to" (Atkinson 2010, 84). We need to continue the type of dialogue for which a book such as Allsup's creates the space. Music education as a discipline needs this dialogue; our students deserve for their classroom teachers and university professors to reflect deeply on many perspectives about what we do as educators and how we do it.

As a reader, I wish Allsup had said more about social justice and how an "open philosophy" might serve an explicitly articulated social justice agenda. I also wish he had painted a more balanced picture of praxial music education. But because the book caused me to trouble those concepts in ways both old and new, Remixing the Classroom may be considered a successful text.

In closing, I want to leave readers with this thought. "That's the problem with writing, very much given to the monologue, to crescendos of rhetoric, never very far away from the scandal of hypnosis ... it's a good way to think but a bad way to listen" (Stronach and MacLure 1997, 18, cited in Atkinson 2010, 84). Let us not allow the crescendos of rhetoric, in Allsup's text or any other, lead us into a state of hypnosis about our own perspectives. My hope is that Remixing the Classroom will open the door to listening with greater intent and respect to and for each other, so that we can engage in meaningful dialogue about music education both for the present and for the future.

\section{About the Author}

Deborah Bradley received a Ph.D. in Sociology \& Equity Studies in Education from OISE/University of Toronto. She was Assistant Professor in the Department of Curriculum and Instruction at the University of Wisconsin-Madison from 2006- 2010, and taught at the University of Toronto from 1997-2005 and 20102014. She retired from UW-Madison in 2010 and the University of Toronto in 2014. Her publications on antiracism education include articles in ACT, Philosophy of Music Education Review, Journal of Aesthetic Education, Music Education Research, Theory into Practice, and chapters in several Oxford University Press handbooks: Philosophy of Music Education (2012), Handbook of Music Education and Social Justice (2015), the Handbook of Choral Pedagogy (2017), and College Music Curricula for a New Century (2017), edited by Robin Moore. Deborah Bradley has served as Editor-in-Chief for MayDay Group Publications since 2016.

Bradley, Deborah. 2017. Agoraphobia and music education: Fear of the closed, fear of the open. Action, Criticism, and Theory for Music Education 16 (1): 38-52. doi:10.22176/act16.1.38 


\section{References}

Allsup, Randall Everett. 2015. Music teacher quality and the problem of routine expertise. Philosophy of Music Education Review 23 (1): 5-24.

Allsup, Randall Everett. 2016. Remixing the classroom: Toward an open philosophy of music education, Counterpoints: Music and education. Bloomington; Indianapolis: Indiana University Press.

Atkinson, Elizabeth. 2010. The responsible anarchist: Postmodernism and social change. British Journal of Sociology of Education 23 (1): 73-87. doi: 10.1080/01425690120102863.

Benedict, Cathy L. 2012. Critical and transformative literacies: Music and general education. Theory into Practice 51 (3): 152-8. doi:10.1080/00405841.2012. 690293 .

Bowman, Wayne. 2002. Educating musically. The new handbook of research on music teaching and learning, edited by Richard Colwell and Carol Richardson, 63-84. New York: Oxford University Press.

Bradley, Deborah. 2006. Music education, multiculturalism, and anti-racism. Action, Criticism, and Theory for Music Education 5 (2).

Bradley, Deborah. 2007. The sounds of silence: Talking race in music education. Action, Criticism, and Theory for Music Education 6 (4): 132-62.

Bradley, Deborah. 2008. Teaching in an unforgiving present for the unknowable future: Multicultural human subjectivity, antiracism pedagogy and music education. In Diverse methodologies in the study of music teaching and learning, edited by Linda Thompson and Mark Robin Campbell, 111-36. Charlotte: Information Age Publishing.

Bradley, Deborah. 2011. In the space between the rock and the hard place: State teacher certification guidelines and music education for social justice. Journal of Aesthetic Education 45 (4): 79-96.

Bradley, Deborah. 2012. Good for what, good for whom? Decolonizing music education philosophies. In The Oxford handbook of philosophy in music education, edited by Wayne Bowman and Ana Lucia Frega, 409-33. New York: Oxford University Press.

Bradley, Deborah. 2017. Standing in the shadows of Mozart: Music education, world music, and curricular change. In College music curricula for a new century, edited by Robin Moore. New York: Oxford University Press. 
Dei, George J. Sefa. 2000. Power, knowledge and anti-racism education. Edited by George Sefa Dei and Agnes Calliste. Halifax: Fernwood Publishing.

Elliott, David J. 1995. Music matters. New York: Oxford University Press.

Elliott, David J., and Marissa Silverman. 2014. Music matters: A philosophy of music education. 2nd ed. New York: Oxford University Press.

Hess, Juliet. 2013. Radical musicking: Challenging dominant paradigms in elementary music education. PhD diss., Department of Humanities, Social Sciences and Social Justice Education, Ontario Institute for Studies in Education, University of Toronto.

Knights, David. 1997. Organization theory in the age of deconstruction: Dualism, gender, and postmodernism revisited. Organization Studies 18 (a):1-19.

Ladson-Billings, Gloria. 1996. "Your blues ain't like mine": Keeping issues of race and racism on the multicultural agenda. Theory into Practice 35 (4): 248-55.

McIntosh, James. 2015. What is agoraphobia? What causes agoraphobia? Medical News Today. [Article]. http://www.medicalnewstoday.com/articles/ 162169.php.

McLaren, Peter. 2011. Radical negativity: Music education for social justice. Action, Criticism, and Theory for Music Education 10 (1): 131-47.

McLaren, Peter, and Ramin Farahmandpur. 2000. Reconsidering Marx in postMarxist times: A requiem for postmodernism? Educational Researcher 29 (3): 1-9.

Moore, Robin. 2017. Music pedagogy for the twenty-first century: Guiding principles. In Music pedagogy for the twenty-first century, edited by Robin Moore.

Morrison, Tony. 1992. Playing in the dark: Whiteness and the literary imagination. New York: Vintage Books. Original edition, Harvard University Press.

O'Toole, Patricia. 1994a. "I sing in a choir but I have no voice!" The Quarterly Journal of Music Teaching and Learning 4/5: 65-76.

O'Toole, Patricia. 1994b. Redirecting the choral classroom: A feminist poststructural analysis of power relations within three choral settings. PhD diss., Curriculum and Instruction, University of Wisconsin.

Bradley, Deborah. 2017. Agoraphobia and music education: Fear of the closed, fear of the open. Action, Criticism, and Theory for Music Education 16 (1): 38-52. doi:10.22176/act16.1.38 
Pollock, Mica. 2004. Colormute: Race talk dilemmas in an American school. Princeton, N.J.: Princeton University Press.

Regelski, Thomas A. 2002. On "methodolatry" and music teaching as critical and reflective praxis. Philosophy of Music Education Reviw 10 (2): 102-23.

Rorty, Richard. 1989. Contingency, irony, and solidarity. New York: Cambridge University Press. Reprint, 1994.

Sarath, Ed, Patricia Shehan Campbell, David Meyers, Juan Chattah, Lee Higgins, Victoria Lindsay Levine, David Rudge, and Timothy Rice. 2014. Transforming music study from its foundations: A manifesto for progressive change in the undergraduate preparation of music majors. 135. http://dx.doi.org/10.18177/sym.2016.56.fr.11118. 